\title{
ARABIC ACQUISITION THROUGH FACEBOOK GROUP LEARNING
}

\author{
Nuril Mufidah, Saidna Zulfiqar Bin-Tahir \\ UIN Maulana Malik Ibrahim Malang, Universitas Iqra Buru Maluku \\ Email: nurilmufidah86@uin-malang.ac.id, saidnazulfiqar@gmail.com
}

\begin{abstract}
:
Facebook is a social media that is very popular with students in Indonesia. Thus, this study attempted to examine the increased of students' Arabic acquisition through Facebook group learning. This research was quantitative research using quasiexperimental design. The sample of this study consists of two classes from the students of the Arabic language education department at UIN Maulana Malik Ibrahim. The instrument of this research was writing test. The results of this study indicated an increase of students' Arabic acquisition of so that it can be concluded that Facebook groups can improve the students' ability to write in Arabic.
\end{abstract}

Keywords: Arabic acquisition, Facebook, writing

\section{A. INTRODUCTION}

In general, the adoption of Arabic learning methods developed by pesantren and educational institutions, including Islamic universities still focuses on grammatical methods - translation. This shows the special features that have been developed by 1) giving the grammatical rules by teachers and memorizing the rules by the students (Cook, 2013; Bin-Tahir, 2015); 2) memorizing certain words which are then coupled according to the grammatical rules applies (Effendy, 2005); 3) activities in translating verbatim, and sentence by sentence from Arabic to student language and vice versa i.e. from the language of the learner into Arabic (Anshor, 2009); 4) the practice for the proficiency of using the language orally and the writing is very less, even if taught, the frequency is only occasional in boring ways because there is no variation (Bin-Tahir, 2017), and 5) deleting visual aids and audiovisual tools (Fuad, 2004).

This situation shows that graduates of religious education institutions are Arabic teaching products based on information approach and grammatical method. Whereas the approach and method to the curriculum is disintegration, that the method does not have a close relationship between Arabic lessons with other subjects. Arabic teaching subjects are split sharply separate parts, whereas language proficiency is not taught to the students. In other words, Arabic lessons are delivered more theoretically because it prioritizes the formation of linguists, not the formation of human beings who can communicate such orally or written. In fact, in today's digital era has provided various alternative approaches and media in improving the results of learning such as Facebook.

Facebook is a social media that is very popular with students in Indonesia. Facebook users worldwide accounted for 250 million users. Based on the results of previous research, Facebook visitors in June 2016 reached 232.1 million, higher than other social networking visitors (Pempek et al., 2009; Tahir \& Aminah, 2014; Tahir, 2015; Sakkir et al., 2016; Sakkir, 2016; Salikin \& Tahir, 2017). In addition to being a means of interaction in cyberspace, Facebook users are not only looking for friends, but 
they can also write notes on the personal and group wall as well as they can upload images that can be read and seen by everyone. The number of users of Facebook as a communication tool, especially students of UIN Maulana Malik Ibrahim made the researchers attempted to measure the students' learning achievement and their ability in writing Arabic in the Facebook group wall.

\section{B. REVIEW OF LITERATURE}

Facebook is a social networking service headquartered in Menlo Park, California, United States that was launched in February 2004. As of September 2012, Facebook has more than one billion active users, more than half using mobile phones (Sagupta, 2012). Users have to register before using this site. After that, users can create personal profiles, add other users as friends, and exchange messages, including automatic notifications when they update their profile. In addition, users can join groups of users with the same interests, sorted by workplace, school or college, or other distinctive features, and group their friends into lists such as "Co-workers" or "Close Friends." This social media can be empowered in teaching and learning a language especially in improving oral and written skills (Tahir \& Aminah, 2014; Sakkir et al., 2016; Salikin \& Tahir, 2017).

Basically, writing means producing or reproducing oral message into written language. It involves an active process to organize, formulate and develop ideas on the paper so that readers can follow the writers' message. Beside, writing skill requires an accurate and precise grammar, spelling, punctuation, capitalization, and vocabulary (Bulte \& Housen, 2014).

Kroma (1988) described that writing is a kind of activity where the writer expresses all the ideas in his mind in the paper from words to sentence, sentence to paragraph and from paragraph to essay. Similarly, Lindblom (1983) defined that writing is a way of learning to focus on our mind to an important matters, and of learning about them. At the same things, Ghaith (2002) described that writing is a complete process that allows writer to explore thoughts and ideas and make them visible and concrete.

The following are the discussions on each of aspect of the writing skill, namely vocabulary skill, and mechanical skill. 1) Vocabulary; In order to compose a good writing narrative text, the students must have a great stock of vocabulary and their meanings. Hornby (1995) defines vocabulary as a list of words with their meaning for understanding and communication; 2) Grammar; Fairbairn and Winch (1996) state that grammar is a set of rules to help the students construct sentences that are reasonable and in acceptable English. It deals with how to form and to use words, phrase, and sentence correctly. In addition, Heaton (1988) says that grammatical skills are the ability to write correct and appropriate sentences; 3) Mechanics is one of the skills in writing narrative text covering the ability to use the conventions in the written form (Heaton, 1988). Furthermore, he states that mechanics refer to punctuation, capitalization, and spelling. In this research, the mechanics used to evaluate the students' writing narrative text were punctuation and capitalization; 4\} Content; In order to have good content of writing narrative text, its content should have been well unified and complete. The term usually known as unity and completeness, which become the characteristics of the good writing narrative text. The main idea has to be explained and develop fully. Completeness is the controlling ideas, which developed thoroughly by the use of particular information (Jacobs, 1981). 


\section{METHOD}

The researcher applied the quasi-experimental design. The design involved two groups, namely experimental group and control group. The experimental group has been treated using Facebook group learning and control group using conventional learning (Gay et al., 2006).

The population of the research was the students of Arabic education department of UIN Maulana Malik Ibrahim in academic year 2016/2017. The sample of this research was selected through random sampling; two classes were selected randomly as the experimental and control group. The class A1 of the second semester was taken as an experimental group and the class B2 was taken as a control group. As a consideration, the students of both classes have the same ability. The total number of sample consists of 30 students in each group.

The researchers employed the writing test to measure the students learning achievement through the pretest to both experimental and control groups before treatment and posttest after treatment. The pretest and posttest focused on students' writing skill using Facebook group wall that covers the acceptable content, appropriate vocabulary, accuracy in grammar, and mechanic in a 1-6 scale of Heaton (1988) score rubric. The students' writing scores have been converted to the sore classification of UIN Maulana Malik Ibrahim, Malang.

\section{RESULTS}

Based on the analysis, the frequency score and the percentage of the students' accuracy in Experimental group and Control Group can be seen in the table 1 as follows:

Table 1: The Frequency and Percentage of the Students' Achievement in the Experimental and Control Group in pretest

\begin{tabular}{llllll}
\hline & & \multicolumn{2}{c}{ Experimental Group } & \multicolumn{2}{c}{ Control Group } \\
\hline Range of score & Classification & $\mathrm{F}$ & $\%$ & $\mathrm{~F}$ & $\%$ \\
\hline $86-100$ & Excellent & 0 & 0 & 0 & 0 \\
$71-85$ & Very good & 0 & 0 & 0 & 0 \\
$56-70$ & Good & 2 & 6.7 & 1 & 3.3 \\
$41-55$ & Average & 8 & 26.7 & 2 & 6.7 \\
$26-40$ & Poor & 20 & 66.7 & 27 & 90.0 \\
$\leq 25$ & Very poor & 0 & 0 & 0 & 0 \\
\hline & Total & 30 & 100 & 30 & 100 \\
\hline
\end{tabular}

Table 1 illustrates that most of the students in experimental and control group were in poor or low category. The aggregate percentage of pretest categorized as low achiever was 20 students (66.7 percent) in experimental and 27 students (90.0) in control group, and high achiever was only 2 students (6.7 percent) in experimental group and 1 student (3.3 percent) in control group. Based on the aggregate of percentage in pretests showed that the low achievers were bigger than high achievers. It indicated that the students speaking skill in term of accuracy is still needed to be improved. The frequency score and the percentage of the students' accuracy in posttest both experimental group and control group can be seen in the table 2 as follows: 
Table 2: The Frequency and Percentage of the Students' Achievement in

Experimental Group and Control Group in posttest

\begin{tabular}{llllll}
\hline & & \multicolumn{2}{c}{ Experimental Group } & \multicolumn{2}{c}{ Control Group } \\
\hline Range of score & Classification & F & $\%$ & F & $\%$ \\
\hline $86-100$ & Excellent & 0 & 0 & 0 & 0 \\
$71-85$ & Very good & 6 & 20.0 & 1 & 3.3 \\
$56-70$ & Good & 24 & 80.0 & 1 & 3.3 \\
$41-55$ & Average & 0 & 0 & 27 & 90.0 \\
$26-40$ & Poor & 0 & 0 & 1 & 3.3 \\
$\leq 25$ & Very poor & 0 & 0 & 0 & 0 \\
\hline & Total & 30 & 100 & 30 & 100 \\
\hline
\end{tabular}

Table 2 illustrates that most of the students in experimentalgroup after the treatment were categorized in very good and good category while in control group were in average category. The aggregate percentage of posttest categorized as very good achiever was 6 students ( 20 percent)and good achiever was 24 students ( 80 percent) in experimental and in control group, only 1 student was categorized as very good achiever (3.3 percent), 1 student was categorized as good achiever (3.3 percent) and 27 students were categorized average achiver (90 percent). In the tables below, the researchers presented the mean score and standard deviation of the Experimental and Control Group.

Table 3 The Mean Score and Standard Deviation of the Students' Pretest and Posttest in experimental group and control group

\begin{tabular}{lcccc}
\hline & Mean & $\mathrm{N}$ & Std. Deviation & Std. Error Mean \\
\hline $\begin{array}{l}\text { Experimental } \\
\begin{array}{l}\text { Pretest } \\
\text { Posttest }\end{array}\end{array}$ & 39.80 & 30 & 10.56 & 3.18 \\
& 70.20 & 30 & 6.50 & 1.25 \\
\hline $\begin{array}{l}\text { Control } \\
\text { Pretest }\end{array}$ & 35.26 & 30 & 7.38 & 2.68 \\
Posttest & 51.10 & 30 & 7.49 & 1.43 \\
\hline
\end{tabular}

The mean score and standard deviation were shown difference in pretest and posttest. The data based on the computation using SPSS version 17.0. From the data in table 3 illustrates the main score of pretest and posttest were different after giving the treatment. This means that there is an improvement after giving the treatment. The table showed that the mean score of the students' pretest in experimental group was 39.80 and standard deviation was 10.56; and in posttest was 70.20 and standard deviation was 6.50. Meanwhile, the mean score of the students' pretest in control group was 35.26 and standard deviation was 7.38; and in posttest the mean score was 51.10 and standard deviation was 7.49. The mean score of both pretest and posttest were different after the treatment executed. It means that the main score of posttest is higher than pretest $(70.20$ $>39.80)$ and $(51.10>35.26)$.

The hypotheses were tested by using inferential analysis. In this case, the researcher used t-test (testing of significance) or paired samples test for independent sample test, that is, a test to know the significance of difference between the result of 
I J A Z A R A B I

Journal of Arabic Learning

p ISSN: $2620-5912$ | e IS SN: $2620-5947$

students' mean scores in all mean score of pretests and posttests as presenting in table below.

Table 4: The Probability Value of T-Test of the Experimental and Control Group Achievement

\begin{tabular}{ccccc}
\hline Experimental Group & $\mathrm{T}$ & $\begin{array}{c}2 \text { Tailed } \\
\text { Value }\end{array}$ & $(\alpha)$ & Remarks \\
\hline Pretest and Posttest & 25.891 & 0.00 & 0.05 & $\begin{array}{c}\text { Significantly } \\
\text { Different }\end{array}$ \\
\hline Control Group & $\mathrm{T}$ & $\begin{array}{c}\text { 2 Tailed } \\
\text { Value }\end{array}$ & $(\alpha)$ & Remarks \\
\hline Pretest and Posttest & 27.182 & 0.00 & 0.05 & $\begin{array}{c}\text { Significantly } \\
\text { Different }\end{array}$ \\
\hline
\end{tabular}

Table 4 showed the probability value of t-test of the experimental and control group achievement. In experimental group, the result of anlysis showed that there were significant different between pretest and posttest where the probability value $(0.00)$ is smaller than the level of significance at t-table (0.05). it can be drawn that the probability value was smaller than $\alpha(0.00<0.05)$. It indicated that alternative hypothesis $\left(\mathrm{H}_{1}\right)$ was accepted and the null hypothesis $\left(\mathrm{H}_{0}\right)$ was rejected. In control groupthe result of analysis of pretest and posttest also showed that there were significant different between pretest and posttest result. The result of analysis showed that the probability value (0.00) is smaller than the level of significance at t-table $(0.05)$ or it can be said that the probability value was smaller than $\alpha(0.00<0.05)$. It indicated that the alternative hypothesis $\left(\mathrm{H}_{1}\right)$ was accepted and the null hypothesis $\left(\mathrm{H}_{0}\right)$ was rejected. Therefore, the researchers concluded that the data of posttest as the final result gave significant improvement. It can be summarized that the use of Facebook group was able to give greater contribution in learning Arabic or the use of Facebook group in learning Arabic can improve the students' writing skill.

\section{E. DISCUSSION}

The results show that the use Facebook group wall significantly improves the students writing skill. Specifically, the result of the mean score in posttest in experimental group shows that of the three aspects of writing content got the highest mean score, then followed by mechanic and the last is grammar. The researchers assumed that the improvement of students' writing skill relating to the students' ability to take in the content written and use them to construct an interpretation of what they think the other writer intended to convey (Harris, 1991). The researchers assumed that during treatments most of students paid attention to the content and use them to construct an interpretation. Besides, the researchers assumed that students were familiar with the topics given by the researchers. Meanwhile the result of data analysis shows that the mean score of students' grammar is lower than content. The researchers assumed that accuracy got the lowest mean score in posttest because students were not accustomed to focus on elements of accuracy especially grammar.

The effectiveness of discussion technique in teaching speaking was supported by some previous findings. Bin Tahir \& Aminah (2014) reported that language learning through Facebook can enhance the students' learning achievement due to their classroom interaction activities and their positive attitude toward the online learning 
because they have opportunities to practice and explore their ideas freely and they increase self-confidence to learn. Other research came from Sakkir et al. (2016) who conducted a study on using the social media of Facebook could improve students' writing achievement significantly. Another research came from Tahir (2015). He reported that Yahoo messenger and voice chat in language learning improved students' language skills where the students are able to maximize their own idea in learning with friends, joyful and interaction.

The findings of several researches about the use of small group discussion such as Facebook in line with the advantages of group discussion by Brown (1994); and Gilstrap and Martin (1975). Brown (1994) states that small group provides opportunities for students initiation, for face to face give and take, for practice and negotiation of meaning, for extended conversational exchange, for students adoption of rules that otherwise be impossible. Gilstrap and Martin (1975) also states some advantages of Facebook group discussion such it involves students directly in the process as they serve as participants, group leaders, and framers of discussion question; it can provide opportunities for all students to participate, particularly if the discussion is carried on in a small group. The researcher assumed that the advantages of Face book group wall had made students interesting in learning Arabic.

\section{F. CONCLUSION}

Based on the result findings and in the previous chapter, the researcher comes to the following conclusions that the use of Facebook group in learning Arabic improved the students' writing skill in term of content, mechanic, and grammar. The result of the data analysis of shows that content got the highest score, then followed by mechanic and the last is grammar. Its mean that there are students can not improve their through Facebook group wall, because only their writing content improved but their accuracy did not improved significanly. Overall, the score of students' posttest score in experimental group is higher than control group. Thus, the researchers recommend to the further researchers to conduct a research in using Facebook group wall but in different kinds of technique.

\section{REFERENCES}

Anshor, A. M. (2009). Pengajaran Bahasa Arab Media dan Metode-Metodenya. Yogyakarta: Teras.

Bin Tahir, S. Z., \& Aminah, A. (2014). Improving Students' Writing Skill Through Facebookat University of IqraBuru. In Conference proceedings. ICT for language learning (p. 235). libreriauniversitaria. it Edizioni.

Bin Tahir, S. Z. (2015a). Improving Students' Speaking Skill through Voice Chat at University of Iqra Buru. Journal of Modern Education Review, 5(3), 296-306.

Bin Tahir, S. Z. (2015b). Multilingual Education in Pesantren Context. Yogyakarta: Deepublish.

Brown, H. D. (1994). Principles of Language Learning and Teaching. United State of America: Prentice Hall Regents.

Bulté, B., \& Housen, A. (2014). Conceptualizing and measuring short-term changes in L2 writing complexity. Journal of Second Language Writing, 26, 42-65.

Cook, V. (2013). Second language learning and language teaching. Routledge.

Effendy, A. F. (2005). Metodologi Pengajaran Bahasa Arab. Malang: Misykat. 
Fairbairn, G., \& Winch, C. (1996). Reading, writing and reasoning: a guide for students. Maidenhead: Open University Press.

Fuad, A. E. (2004). Metodologi Pengajaran Bahasa Arab. Malang: Misykat.

Gay, Lorraine. R. (2006). Educational Research: Competencies for Analysis and Application. Eight Edition. New Jersey: Upper Saddle River.

Ghaith, G. M. (2002). The relationship between cooperative learning, perception of social support, and academic achievement. System, 30(3), 263-273.

Giltrap, Robert L. and William R. Martin. 1975. Current Strategies for Teachers: a Resource for Personalizing Instruction. Santa Monica, California: Goodyear. Publishing Company, inc.

Harris, J. (1991). After Dartmouth: Growth and Conflict in English. College English, 53(6), 631-646.

Heaton, James. B. (1988). Writing English Language Test. New York: Longman Group.

Hornby, A.S. (1995). Oxford Advanced Learners' Dictionary. New York: Oxford University Press.

Jacobs, H. L. (1981). Testing ESL Composition: A Practical Approach. English Composition Program. Newbury House Publishers, Inc., Rowley, MA 01969.

Kroma, S. (1988). Action Research in teaching composition. English Teaching Forum. Vol. 26(1), pp. 43-45.

Pempek, T. A., Yermolayeva, Y. A., \& Calvert, S. L. (2009). College students' social networking experiences on Facebook. Journal of applied developmental psychology, 30(3), 227-238.

Sengupta, S. (2012). "Facebook's Prospects May Rest on Trove of Data". The New York Times. Diakses tanggal May 15, 2016.

Sakkir, G., Rahman, Q., \& Salija, K. (2016). Students' Perception on Social Media in Writing Class at STKIP Muhammadiyah Rappang, Indonesia. International Journal Of English Lingusitics, 6(3), 170-175.

Sakkir, G. (2016). Interest and Writing Skill of the University Students on Using Social Media- Facebook in Writing Class (STKIP Muhammadiyah Rappang, Indonesia). Asian EFL Journal (Second Language Acquisition- Academic Research) TESOL Indonesia International Conference Edition. Vol. 2, 178- 188.

Salikin, H., \& Tahir, S. Z. B. (2017). The Social Media-Based Approach in Teaching Writing at Jember University, Indonesia. International Journal of English Linguistics, 7(3), 46.

Tahir, S. Z. A. B. (2015). Improving Students' Speaking Skill through Yahoo Messenger at University of Iqra Buru. International Journal of Language and Linguistics, 3(3), 174-181. 